\title{
Исследование зон быстрого транзита карстовых подземных вод Южного берега Крыма
}

Богуславский А.С., Казаков С.И., Лемешко Е.Е., Берзова И.Г. ФГБУН Черноморский гидрофизический полигон РАН, п.г.m. Качивели, Республика Крым, science@bshpg-ras.ru

Аннотация. Приведены результаты геоморфологического анализа и гидрогеологического моделирования быстрого транзита подземных вод карстового формирования через береговую зону Южного берега Крыма по трассам древних оползней и отторженцев на примере участков тектонического обрамления Лименской вулканической группы (г. Пиляки-Хыр). Обосновывается палеореконструкция формирования древних оползней и известняковых отторженцев как объектов дилювиального (флювиально-катастрофического) морфолитогенеза.

Ключевые слова: Горный Крым, береговая зона, древние оползни, известняковые отторженцы, дилювий, гидрогеологическая модель, палеореконструкция.

\section{Studying fast transit zones of the karst groundwater of the Southern coast of Crimea}

\author{
Boguslavsky A.S., Kazakov S.I., Lemeshko E.E., Berzova I.G. \\ Black Sea Hydrophysical Proving Ground of the Russian Academy of Sciences, Katsiveli, Republic of \\ Crimea, science@bshpg-ras.ru
}

\begin{abstract}
The paper presents results of geomorphological analysis and hydrogeological modeling of fast transit flow of karst groundwater across the shore by pathways of ancient landslides and limestone outliers of the Southern coast of Crimea on the example of sites of tectonic framing of the Limenian volcanic group (Pilyaki-Hyr mountain). The article substantiates paleoreconstruction of the formation of ancient landslides and limestone outliers as objects of diluvium (fluvial-catastrophic) morpholithogenesis.
\end{abstract}

Key words: Mountain Crimea, coastal zone, ancient landslides, limestone outliers, diluvium, hydrogeological model, paleoreconstruction.

\section{Введение}

Актуальность проблемы исследования трансберегового транзита и разгрузки подземных вод карстового формирования юго-западной части Горного Крыма и Южного берега Крыма (ЮБК) определяется, во-первых, необходимостью уточнения механизмов формирования береговых ландшафтов, в частности, в аспекте гипотезы катастрофических флювиогляциальных (дилювиальных) процессов формирования ландшафтов в голоцене (Рудой, 1997, 2000), предварительно подтверждаемых циклическим (грядовым) характером разброса обломков верхнеюрских известняков в береговой зоне ЮБК.

Во-вторых, важность проблемы обусловлена непосредственной связью потоков подземных вод и их выходов на поверхность с опасными инженерно-геологическими явлениями и процессами береговой зоны - оползнями, обвалами, абразией, селями, мутьевыми потоками, зонами повышенной сейсмической балльности, и, следовательно, с необходимостью разработки эффективного менеджмента и устойчивости берегов, решения геоэкологических проблем.

Более-менее детальные геолого-геоморфологические и немногочисленные гидрогеологические исследования береговой территории ЮБК и прилегающих с севера склонов Горного Крыма исследуемого Лименского участка были выполнены в работах А.С. Моисеева (Моисеев, 1930), С.Н. Михайловского и В.Ф. Пчелинцева (Михайловский, Пчелинцев, 1932), в которых высказывается идея о приуроченности струйных потоков подземных вод к известняковым массивам древних оползней и отторженцев, расположеных вдоль тектонических нарушений по границам Лименского вулканического района (Лебединский, Макаров, 1962). Особенностью этих массивов являет- 
ся наличие в них разнородных по размеру и характеру залегания перемещенных блоков верхнеюрских известняков (от щебней до глыб размерами в десятки метров и весом в сотни тонн). В древних оползнях ЮБК они залегают во вмещающих элювиально-делювиальных суглинистых оползневых отложениях, представляя в целом оползневые массивы предположительно неоген-четвертичного возраста. Отторженцы (Биюк-Исар, Кошка, Могаби, Массандровский массив, Парагильмен, Гурзуфские скалы и др.) представляют собой смещенные массивы трещиноватых известняков компактного залегания и значительных размеров (от сотен метров до километров), первоначально, по-видимому, принадлежавших Главной гряде. М.В. Муратов (Муратов, 1960) назвал их массандровскими отложениями (свитой) ввиду их большого массива в районе Массандры, и небезосновательно связывал их происхождение с оползневыми процессами и водно-селевыми потоками по наклонным к югу ложбинам и палеоруслам древних водотоков. Относительно происхождения этих отложений до настоящего времени в литературе нет единого мнения. Как вполне вероятные рассматриваются также тектонический и сейсмогравитационный механизмы их смещения с плато яйл Главной гряды (Вахрушев, 2000).

\section{Геоморфологические особенности}

Результаты исследования геоморфологических особенностей известняковых отторженцев и древних оползней исследуемого Лименского участка подтверждают высокую вероятность их дилювиального генезиса (Рудой, 1997, 2000) и тесную взаимосвязь с геодинамическими зонами по тектоническому обрамлению Лименской вулканической группы (Лебединский, Макаров, 1962). Все отторженцы как Симеизской (г. Кошка), так и Кучук-Койской (Биюк-Исар) групп, соответственно к востоку и западу от древнего вулкана г. Пиляки-Хыр, выявляют субмеридионально ориентированные обтекаемые формы, характерные для потоковых друмлинов и котловин (Baker and Nummedal, 1978).

Скелетную «осевую» основу Кацивельского и Понизовского древних оползней составляет непрерывный «хаос» обломков верхнеюрского известняка от щебней до глыб размерами 10 м и более, который прослеживается от спиллвея (Рудой, 1997) - ущелья прорыва в Главной гряде к югу от котловины Бештекне - по палеоруслу вдоль западного склона г. Пиляки-Хыр и далее до бере-



Рис. 1. Верхняя часть Кацивельско-Понизовского древнего оползня. Внизу слева - вулканический массив г. Хыр, справа - группа отторженцев Биюк-Исар.

Fig. 1. The upper part of the Katsiveli-Ponizovka ancient landslide. Bottom left - the volcanic massif of Mt. Hyr, right - a group of the Biyuk-Isar outliers. говой линии и подводного склона. Вблизи Главной гряды обломки лежат на поверхности в виде мощных хаотических навалов (рис. 1).

По мере углубления, расширения и разветвления палеорусла в южном направлении на кацивельскую и понизовскую ветви, глыбы известняков все более «утоплены» в суглинистых вмещающих отложениях мощностью до 50 м, формируя, наряду с более мелкими обломками терригенных и вулканогенных пород, тело древних оползней (рис. 2).

Вдоль восточной и западной границ их прибрежной части отдельные глыбы известняков формируют поверхностные эрратические шлейфы - дилювиальные бермы (Рудой, 1997) на примыкающих обнажениях коренных пород таврической серии (рис. 3). 


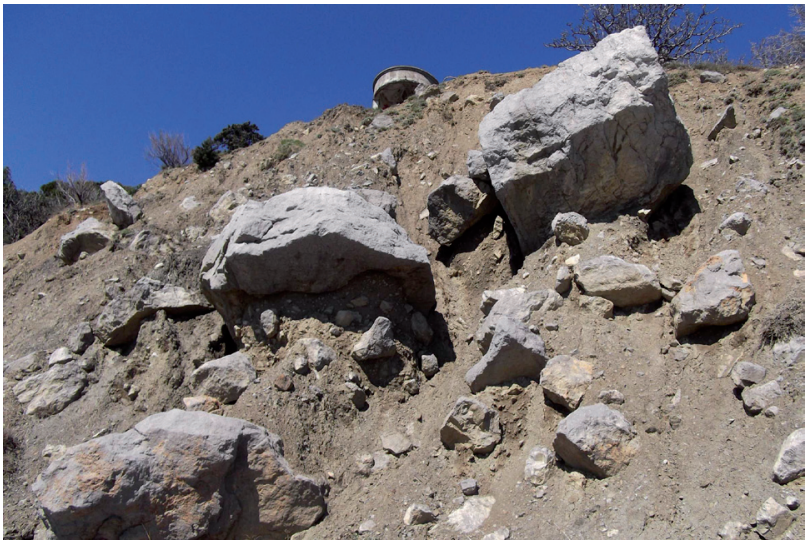

Рис. 2. Верхнеюрские обломки известняка в теле вмещающих суглинистых оползневых отложений древнего Кацивельского оползня (береговой обрыв, мыс Кикинеиз).

Fig. 2. Upper-Jurassic limestone fragments within hast loamy landslide deposits of the ancient Katsiveli landslide (coastal cliff, Cape Kikineiz).

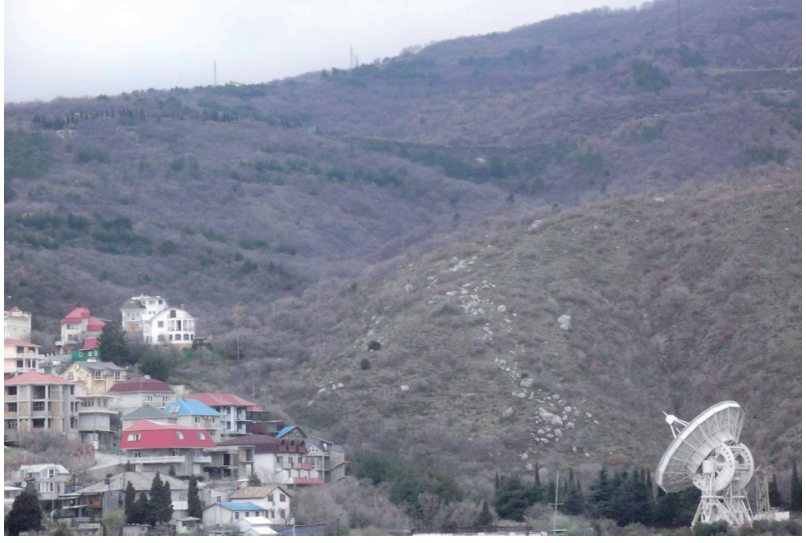

Рис. 3. Субмеридиональные эрратические шлейфы обломков известняков вдоль восточной границы Кацивельского древнего оползня, берег Лименской бухты, радиотелескоп РТ-22.

Fig. 3. Submeridional erratic traces of limestone debris along the eastern border of the Katsiveli ancient landslide, the coast of Limensky Bay, Radiotelescope RT-22.

\section{Гидрогеологическая модель}

С помощью компьютерной моделирующей системы Processing Modflow (Ciang, Kinzelbach, $2001)$ разработана двухслойная гидрогеологическая модель участка ЮБК (район Понизовка - Си-

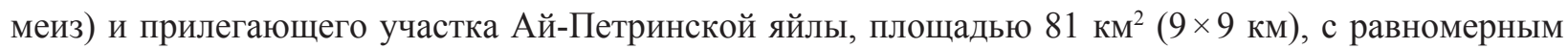
шагом квадратной сетки 100 м. Выполнено моделирование потоков подземных вод по зонам повышенной проницаемости, обусловленным субмеридиональными разломами по границам вулканогенного (г. Пиляки-Хыр) и терригенного комплексов, которые геоморфологически ассоциируются с древними оползнями и известняковыми отторженцами (г. Кошка, г. Биюк Исар).

В процессе создания модели учитывались: отметки рельефа по данным топокарты М 1:50000 и детальных космоснимков (Landsat, Quick Bird); уровни подземных вод в имеющихся скважинах; данные о субмаринной разгрузке; данные атмосферных осадков; рельеф дна подводного берегового склона (Мельник, 1996); результаты георадарного профилирования массива пород Кацивельского древнего оползня с использованием георадара «SIR-3000» с целью уточнения параметров проницаемости (рис. 4).



Рис. 4. Радарограмма субширотного профиля поперек древнего Кацивельского оползня (длина 200 м, глубина 15 м). А - поверхностные отложения; В - известняковые монолиты и обломки; $\mathrm{C}$ - коренные породы таврической серии.

Fig. 4. Radarogram of a sublatitudinal profile across the ancient Katsiveli landslide (length $200 \mathrm{~m}$, depth $15 \mathrm{~m}$ ). A - superficial deposits; $\mathrm{B}$ - limestone monoliths and debris; $\mathrm{C}$ - base rocks of the Taurian suite. 


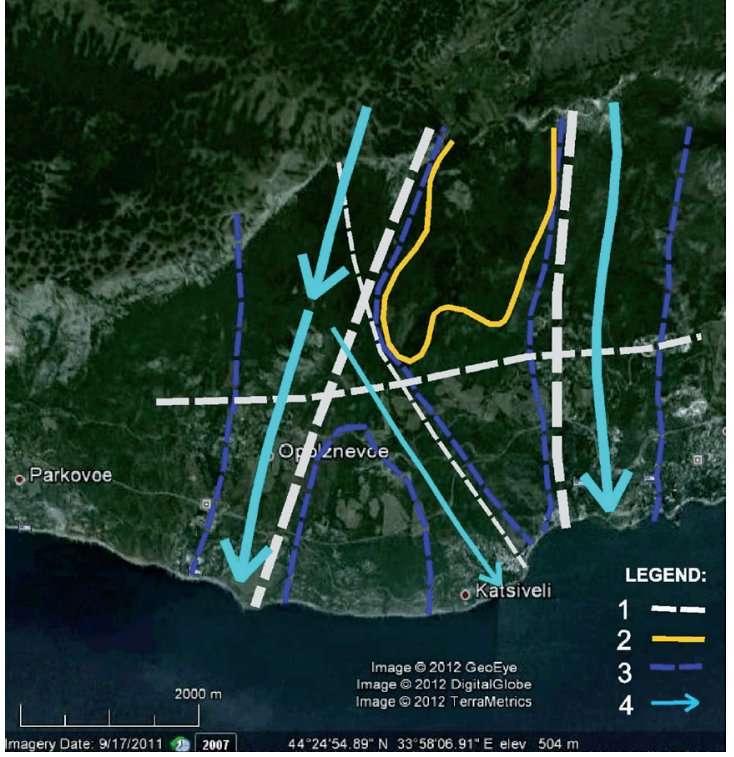

Рис. 5. Потоки подземных вод через береговую зону Лименского участка. 1 - тектонические разломы; 2 - граница вулканического массива Пиляки-Хыр; 3 - границы древних оползней и отторженцев; 4 - направления потоков.

Fig. 5. Groundwater flows across the coastal zone of the Limensky site. 1 - tectonic faults; 2 - boundary of the volcanic massif Pilaki-Hyr; 3 - boundaries of ancient landslides and outliers; 4 - flow directions.

Исследование древних оползней и известняковых отторженцев ЮБК представляет научный и практический интерес в ряде аспектов. С точки зрения инженерной геологии, эти массивы являются относительно устойчивыми, ввиду их прочной связи с вмещающими и коренными породами, а их хаотические навалы вдоль береговой линии служат надежной «броней», защищающей естественные берега от абразии. С гидрогеологической точки зрения, они представляют потенциальные зоны быстрой фильтрации подземных вод карстового формирования, которые на предгорном склоне имеют многочисленные выходы родников, а на подводном прибрежном склоне - зоны субмаринной разгрузки.

Условия формирования, гидрогеологические условия, состав почвогрунтов, сохранившийся растительный и животный мир древних оползней и отторженцев ЮБК, а также ихтиофауна и бентос их прибрежных подводных участков, делают их уникальными экологическими природными заповедниками, требующими бережного отношения и охраны.

Работа выполнена при поддержке Программы президиума РАН № 19 «Фундаментальные проблемы геолого-геофизического изучения литосферных процессов» государственного задания № 075-00803-19-00.

\section{Литература}

1. Вахрушев И.Б. Природа скал Адалар у Южного берега Крыма // Культура народов Причерноморья. 2000. № 14. С. 11-14.

2. Лебединский В.И., Макаров Н.М. Вулканизм Горного Крыма. Изд. АН УССР. Киев. 1962. 209 с.

3. Мельник В.И. Мезоформы рельефа материкового склона Черного моря // Геологический журнал. № 1-2. Киев. 1996. С. 123-131. 
4. Михайловский С.Н., Пчелинцев В.Ф. Гидрогеологические исследования в Кучук-койском и Кикенеизском районах Южного Берега Крыма. Гидрогеологические исследования в Леменском районе Южного Берега Крыма. Гос. научно-техническое и геологоразведочное изд-во: М-Л. 1932. 187 с.

5. Моисеев А.С. К геологии юго-западной части Главной гряды Крымских гор. Изд-во Геологического комитета. Л. 1930. 88 с.

6. Муратов М.В. Геологическое прошлое Крыма и Черного моря // Природа. 1960. № 6. С. 57-64.

7. Рудой А.Н. Основы теории дилювиального морфолитогенеза // Известия РГО. 1997. Т. 129. Вып. 1. С. 12-22.

8. Рудой A.Н. Ледниковые катастрофы в новейшей истории Земли // Природа. 2000. № 9. С. 36-45.

9. Baker V.R. and Nummedal D. (Editors). The channeled scabland. A guide to the geomorphology of the Columbia Basin, Washington. Comparative Planetary Geology Field Conference, Columbia Basin, June 5-8. 1978. NASA. 1978. $186 \mathrm{p}$.

10. Ciang W.H, Kinzelbach W. 3D Groundwater modeling with PMWin. Springer, 2001. 346 p. 